\title{
Inhibitors of Angiotensin-converting Enzyme or Block- ers of Angiotensin-2 Receptor in COVID-19 Patients With Comorbid Cardiovascular or Pulmonary Diseases
}

\author{
Farid Rahimi' $^{1}$, Amin Talebi Bezminabadi ${ }^{*}$ (D) \\ 1. Research School of Biology, Australian National University, Canberra, Australia. \\ 2. Department of Bacteriology, Faculty of Medical Sciences, Tarbiat Modares University, Tehran, Iran.
}

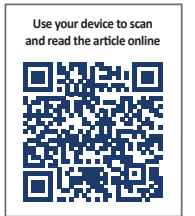

Citation Rahimi F, Talebi Bezminabadi A. Inhibitors of Angiotensin-converting Enzyme or Blockers of Angiotensin-2 Receptor in COVID-19 Patients With Comorbid Cardiovascular or Pulmonary Diseases. Research in Molecular Medicine. 2020; 8(3):103-106. https://doi.org/10.32598/rmm.8.3.851.6

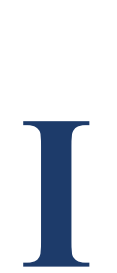

n January 2020, the World Health Organization (WHO) announced the COVID-19 outbreak, caused by SARS-CoV-2, a publichealth emergency [1]. Following the skyrocketing spread of SARS-CoV-2 into more than 210 countries, diverse clinical strategies have been urgently explored against the COVID-19 pandemic while a magic-bullet antiviral vaccine or treatment is unavailable [2]. Although the clinical features of COVID-19 and the epidemiological characteristics of the pandemic have been described, COVID-19 has seemingly evolved, and its new symptoms and associations are being reported over time [3-7]. Nevertheless, SARS-CoV-2 is extremely contagious and new to the human immune system; thus, everyone is vulnerable.

Though many affected by SARS-CoV-2 had shown mostly mild symptoms and many have recovered, a considerable proportion of patients would likely suffer from severe life-threatening symptoms and poor prognoses. For example, individuals with cardiovascular diseases or chronic pulmonary diseases constitute a high-risk group, sadly showing a high mortality rate and poor prognoses. Presently, no sophisticated clinical trial is underway to test the potential side-effects of the presently prescribed medications in the COVID-19 patients (for example, administration of inhibitors of angiotensin-converting enzyme 2 [ACE2] and angiotensin II receptor blockers)
[8-10]. Thus, such recommendations should be considered carefully because of the likely emergence of the cardiovascular toxicity [11].

ACE2 is a dipeptidyl carboxypeptidase expressed on the surface of endothelial cells, intestinal cells, renal glomerular and tubular cells, and cardiac myocytes and pericytes [12-16]. ACE2 is highly expressed in the pulmonary type-II alveolar cells [13] and functions as part of the renin-angiotensin-aldosterone system. This system begins with angiotensinogen, which is produced in the liver and released into the bloodstream. First, renin secreted by the renal juxtaglomerular apparatus converts angiotensinogen to angiotensin I. Then, the latter is converted into angiotensin II by angiotensin-converting enzyme, ACE, which is mainly produced in the lungs. Next, angiotensin II binds to the angiotensin II type 1 receptor on the surface of blood vessels (lung, and myocytes among others) to act as a vasoconstrictor and regulate inflammation and immune responses [17].

On the other hand, activation of angiotensin II type 2 receptor by angiotensin II causes vasodilation. Meanwhile, cell-surface ACE2 is cleaved and activated by ADAM metallopeptidase domain 17. In parallel, active ACE2 is released into the interstitial spaces where it converts angiotensin I to angiotensin 1-9 and angiotensin II to angiotensin 1-7 which binds to MAS receptors and

* Corresponding Author:

Amin Talebi Bezminabadi, PhD.

Address: Department of Bacteriology, Faculty of Medical Sciences, Tarbiat Modares University, Tehran, Iran.

Phone: +98 (912) 0310214

E-mail: amin.talebi@modares.ac.ir 
causes the counter-regulatory function, i.e., vasodilation. Vasoconstriction causes hypertension, which may contribute to acute respiratory distress syndrome [17, 18]. Based on the understanding of this system, excess recombinant ACE2 has been proposed to lure the virus into binding it instead of binding cell-surface ACE2. Luring the virus is then thought to protect the endogenous ACE2 to counterbalance the function of ACE, ideally protecting against viral damage to the lung and heart [19].

Accordingly, on April 2, 2020, Apeiron Biologics was awarded a regulatory authorization [19] to initiate the phase II clinical trials for testing APN01 on 200 patients with severe COVID-19 symptoms. This rationale is in contrast to using ACE2 inhibitors because APN01 is the recombinant human ACE2 that could potentially lure SARS-CoV-2 away from entering into its target cells and reduce lung injury when circulating in excess in the bloodstream and interstitial spaces. This proposal was tested in a cell-culture model with positive results [20]. Besides vasoregulation, ACE2 binds to the neutral amino acid transporter $\mathrm{B}^{0} \mathrm{AT} 1$ (SLC16A19) to facilitate the cell-surface expression of this transporter on the luminal surface of intestinal epithelial cells. Based on this interaction, ACE2 deficiency has been shown to critically impair tryptophan and nicotinamide homeostasis in mice [21]. Also, it increases the susceptibility to intestinal inflammation and colitis, changes the composition of the intestinal microbiome, and alters the expression of some antimicrobial peptides [21]. Thus, any proposed therapy using ACE2 inhibitors will potentially have gastrointestinal, renal, cardiac, pulmonary, and metabolic implications $[5,8,11,12,18,20-23]$.

High rates of cardiac effects were reported by Chen et al. when $\approx 75$ out of 99 COVID-19 patients presented with high levels of lactate dehydrogenase [24]. Collapsing glomerulopathy has recently been studied and reported in one case [7]. While the initial data were reported of patients who were admitted to a hospital in Wuhan, Hubei Province, China, collective data from other countries - especially from Iran, Italy, South Korea, and the United States - now present an evolving picture of the viral pathogenesis, recently presenting with rare symptoms similar to toxic shock and Kawasaki disease in young children $[5,22]$.

Antiviral therapy, immunotherapy, anti-inflammatory therapy, and application of prophylactic vaccines have been recommended in the management of COVID-19, but no definitive intervention has been validated to treat the patients. How SARS-CoV-2 infection directly affects the cardiovascular system is unknown while acute and chronic cardiac damage, ventricular dysfunction, heart failure, arrhythmias, and acute coronary syndromes have been reported $[11,23]$. Furthermore, the other pathogenic mechanisms underlying this viral infection are largely unclear. Thus, it is risky to administer any untested intervention to urgently treat the vulnerable COVID-19 patients with comorbid cardiovascular diseases, chronic pulmonary diseases, or gastrointestinal conditions.

Using the ACE2 inhibitors in such patients has not been validated, and further research is needed to achieve useful evidence-based facts for directing therapy. Despite the fast pace of the pandemic, any recommended treatment must first pass initial clinical and para-clinical testing.

\section{Ethical Considerations}

\section{Compliance with ethical guidelines}

All ethical principles were considered in this article.

\section{Funding}

This research did not receive any grant from funding agencies in the public, commercial, or non-profit sectors.

\section{Authors contribution's}

Both authors contributed equally in preparing all parts of the research.

\section{Conflict of interest}

The authors declared no conflict of interest.

\section{References}

[1] The World Health Organization (WHO). Novel Coronavirus (2019-nCoV): Situation Report-11 [Internet]. 2020 [Updated 2020 Jan 31; Cited 2020 Apr 30]. Available from: https://www.who.int/docs/default-source/ coronaviruse/situation-reports/20200131-sitrep-11-ncov. pdf?sfvrsn=de7c0f7_4.

[2] Heymann DL, Shindo N. Scientific WHO, technical advisory group for infectious H. COVID-19: What is next for public health? Lancet. 2020; 395(10224):542-5. [DOI:10.1016/S01406736(20)30374-3]

[3] Centers for Disease Control and Prevention (CDC). Stop the spread of rumors [Internet]. 2020 [Updated 2020 Apr 4; Cited 2020 Apr 29]. Available from: https:/ /www.cdc.gov/ coronavirus/2019-ncov/daily-life-coping/share-facts.html. 
[4] Centers for Disease Control and Prevention (CDC). Symptoms of Coronavirus [Internet]. 2020 [Updated 2020 Apr 4; Cited 2020 Apr 29]. Available from: https://www.cdc.gov/ coronavirus/2019-ncov/symptoms-testing/symptoms. html.

[5] Pianegonda E. What is Kawasaki disease, what are the symptoms and is it linked to coronavirus? - ABC News: Abcnews [Internet]. 2020 [Updated 2020 Apr 4; Cited 2020 Apr 29]. Available from: https://www.abc.net.au/news/2020-0429/kawasaki-disease-symptoms-is-it-linked-coronavirusin-australia/12197008.

[6] Yeager A. Lost smell and taste hint COVID-19 can target the nervous system: The scientist [Internet]. 2020 [Updated 2020 24 Mar; Cited 2020 Apr 30]. Available from: https://www. the-scientist.com/news-opinion/lost-smell-and-taste-hintcovid-19-can-target-the-nervous-system-67312.

[7] Kissling S, Rotman S, Gerber C, Halfon M, Lamoth F, Comte D, et al. Collapsing glomerulopathy in a COVID-19 patient. Kidney Int. 2020; 98(1):228-31. [DOI:10.1016/j. kint.2020.04.006] [PMID] [PMCID]

[8] Sommerstein R, Kochen MM, Messerli FH, Grani C. Coronavirus Disease 2019 (COVID-19): Do angiotensin-converting enzyme inhibitors/angiotensin receptor blockers have a biphasic effect? J Am Heart Assoc. 2020; 9(7):e016509. [DOI:10.1161/JAHA.120.016509] [PMID]

[9] Guo J, Huang Z, Lin L, Lv J. Coronavirus Disease 2019 (COVID-19) and Cardiovascular Disease: A viewpoint on the potential influence of angiotensin-converting enzyme inhibitors/angiotensin receptor blockers on onset and severity of Severe Acute Respiratory Syndrome Coronavirus 2 Infection. J Am Heart Assoc. 2020; 9(7):e016219. [DOI:10.1161/ JAHA.120.016219]

[10] Driggin E, Madhavan MV, Bikdeli B, Chuich T, Laracy J, Biondi-Zoccai G, et al. Cardiovascular considerations for patients, health care workers, and health systems during the COVID-19 pandemic. J Am Coll Cardiol. 2020; 75(18):2352-71. [DOI:10.1016/j.jacc.2020.03.031] [PMID] [PMCID]

[11] Zheng YY, Ma YT, Zhang JY, Xie X. COVID-19 and the cardiovascular system. Nat Rev Cardiol. 2020; 17(5):259-60. [DOI:10.1038/s41569-020-0360-5] [PMID] [PMCID]

[12] Zhang H, Kang Z, Gong H, Xu D, Wang J, Li Z, et al. The digestive system is a potential route of 2019-nCov infection: A bioinformatics analysis based on single-cell transcriptomes. Bio Rxiv. 2020; 1-26. [DOI:10.1101/2020.01.30.927806]

[13] Zou X, Chen K, Zou J, Han P, Hao J, Han Z. Single-cell RNA-seq data analysis on the receptor ACE2 expression reveals the potential risk of different human organs vulnerable to 2019-nCoV infection. Front Med. 2020; 14(2):185-92. [DOI:10.1007/s11684-020-0754-0] [PMID] [PMCID]

[14] Patel AB, Verma A. COVID-19 and angiotensin-converting enzyme inhibitors and angiotensin receptor blockers: What is the evidence? J Am Med Assoc. 2020; 323(3):56-267. [DOI:10.1001/jama.2020.4812] [PMID] [PMCID]

[15] Hamming I, Timens W, Bulthuis ML, Lely AT, Navis G, van Goor $\mathrm{H}$. Tissue distribution of ACE2 protein, the functional receptor for SARS coronavirus: A first step in understanding SARS pathogenesis. J Pathol. 2004; 203(2):631-7. [DOI:10.1002/path.1570] [PMID] [PMCID]
[16] Baraniuk C. Receptors for SARS-CoV-2 present in wide variety of human cells [Internet]. 2020 [Updated Apr 29; Cited 2020 Apr 30]. Available from: https://www.the-scientist. $\mathrm{com} /$ news-opinion/receptors-for-sars-cov-2-present-inwide-variety-of-human-cells-67496.

[17] Bernstein KE. Two ACEs and a heart. Nature. 2002; 417(6891):799-802. [DOI:10.1038/417799a] [PMID]

[18] Xiao L, Sakagami H, Miwa N. ACE2: The key molecule for understanding the pathophysiology of severe and critical conditions of COVID-19: Demon or angel? Viruses. 2020; 12(5):491. [DOI:10.3390/v12050491] [PMID] [PMCID]

[19] Yeager A. Blood pressure meds point the way to possible COVID-19 treatment [Internet]. 2020 [Updated 2020 Apr 02 Cited 2020 May 03]. Available from: https://www.the-scientist.com/news-opinion/blood-pressure-meds-point-theway-to-possible-covid-19-treatment-67371.

[20] Alhenc-Gelas F, Drueke TB. Blockade of SARS-CoV-2 infection by recombinant soluble ACE2. Kidney Int. 2020; 97(6):1091-3. [DOI:10.1016/j.kint.2020.04.009] [PMID] [PMCID]

[21] Hashimoto T, Perlot T, Rehman A, Trichereau J, Ishiguro $\mathrm{H}$, Paolino $\mathrm{M}$, et al. ACE2 links amino acid malnutrition to microbial ecology and intestinal inflammation. Nature. 2012; 487(7408):477-81. [DOI:10.1038/nature11228] [PMID] [PMCID]

[22] American Academy of Pediatrics. Rare illness linked to coronavirus kills New York five-year-old [Internet]. 2020 [Updated 2020 May 09]. Available from: https://www.9news. com.au/world/coronavirus-kawasaki-disease-toxicshock-child-dies-new-york-covid19/ fce71ec7-867c-43aaab41-0e43d600d256?ocid=edm-nine.com.au-ninedaily-200509\&mktg_scr=edm-ninedaily.

[23] Zaman S, MacIsaac AI, Jennings GLR, Schlaich M, Inglis SC, Arnold R, et al. Cardiovascular disease and COVID-19: Australian/New Zealand consensus statement. Med J Aust. 2020; Online Ahead of Print. [DOI:10.5694/mja2.50714] [PMID]

[24] Chen N, Zhou M, Dong X, Qu J, Gong F, Han Y, et al. Epidemiological and clinical characteristics of 99 cases of 2019 novel coronavirus pneumonia in Wuhan, China: A descriptive study. Lancet. 2020; 395(10223):507-13. [DOI:10.1016/ S0140-6736(20)30211-7 
This Page Intentionally Left Blank 